\title{
Simultaneous Heterotrophic Nitrification and Aerobic Denitrification by Chryseobacterium sp. R31 Isolated from Abattoir Wastewater
}

\author{
Pradyut Kundu, ${ }^{1}$ Arnab Pramanik, ${ }^{2}$ Arpita Dasgupta,, \\ Somnath Mukherjee, ${ }^{1}$ and Joydeep Mukherjee ${ }^{2}$ \\ ${ }^{1}$ Department of Civil Engineering, Jadavpur University, Kolkata 700 032, India \\ ${ }^{2}$ School of Environmental Studies, Jadavpur University, Kolkata 700 032, India \\ Correspondence should be addressed to Joydeep Mukherjee; joydeep_envstu@school.jdvu.ac.in
}

Received 24 February 2014; Accepted 29 April 2014; Published 2 June 2014

Academic Editor: Eugénio Ferreira

Copyright (C) 2014 Pradyut Kundu et al. This is an open access article distributed under the Creative Commons Attribution License, which permits unrestricted use, distribution, and reproduction in any medium, provided the original work is properly cited.

\begin{abstract}
A heterotrophic carbon utilizing microbe (R31) capable of simultaneous nitrification and denitrification (SND) was isolated from wastewater of an Indian slaughterhouse. From an initial COD value of $583.0 \mathrm{mg} / \mathrm{L}, 95.54 \%$ was removed whilst, from a starting $\mathrm{NH}_{4}{ }^{+}-\mathrm{N}$ concentration of $55.7 \mathrm{mg} / \mathrm{L}, 95.87 \%$ was removed after $48 \mathrm{~h}$ contact. The concentrations of the intermediates hydroxylamine, nitrite, and nitrate were low, thus ensuring nitrogen removal. Aerobic denitrification occurring during ammonium removal by R31 was confirmed by utilization of both nitrate and nitrite as nitrogen substrates. Glucose and succinate were superior while acetate and citrate were poor substrates for nitrogen removal. Molecular phylogenetic identification, supported by chemotaxonomic and physiological properties, assigned $\mathrm{R} 31$ as a close relative of Chryseobacterium haifense. $\mathrm{The}^{\mathrm{N}}{ }_{4}{ }^{+}-\mathrm{N}$ utilization rate and growth of strain $\mathrm{R} 31$ were found to be higher at $\mathrm{C} / \mathrm{N}=10$ in comparison to those achieved with $\mathrm{C} / \mathrm{N}$ ratios of 5 and 20. Monod kinetic coefficients, half saturation concentration $\left(K_{s}\right)$, maximum rate of substrate utilization $(k)$, yield coefficient, $(Y)$ and endogenous decay coefficient $\left(K_{d}\right)$ indicated potential application of R31 in large-scale SND process. This is the first report on concomitant carbon oxidation, nitrification, and denitrification in the genus Chryseobacterium and the associated kinetic coefficients.
\end{abstract}

\section{Introduction}

Conventionally, ammonium from abattoir wastewater is removed in sequential operations through alternate aerobic and anoxic periods over time [1-3]. Majority of the carbon is degraded during the aerobic nitrification phase and the residual carbon is used up during the anoxic denitrification phase [4]. However, such systems are prone to operational hindrances due to reduced rate of nitrification and the difficulty to separate nitrification and denitrification reaction processes. Meyer et al. [5] noted that nitrification and denitrification would be incompletely coupled to each other due to nonformation of aerobic/anoxic zones within the microbial aggregates, resulting in buildup of $\mathrm{NO}_{x}{ }^{-}$in the reactor. In comparison with the conventional nitrification and denitrification of abattoir wastewater, several advantages of a shortcut nitrogen removal method via nitrite, through partial nitrification followed by denitrification (PND), have been reported recently [6].

Zheng et al. [7] observed that both nitrification and denitrification could take place concomitantly in a single reactor under identical reaction conditions through a process known as simultaneous nitrification and denitrification (SND). This procedure neither requires large reactor volume nor incurs high energy costs necessary for circulating liquid between aerobic and anoxic systems. Furthermore, SND processes are characterized by increased nitrogen removal rates and decreased reaction time. The key point in the PND process is maintaining the production rate of nitrite by ammonium oxidizing bacteria $(\mathrm{AOB})$ higher than the production rate of nitrate by nitrite oxidizing bacteria (NOB) so that nitrite accumulation can be achieved [6]. 
In contrast, maintenance of a population balance is not necessary in SND as the two reactions (nitrification and denitrification) proceed under identical reaction conditions. Thus, SND is advantageous over PND. Furthermore, the SND process prevents accumulation of $\mathrm{NO}_{x}{ }^{-}$in the system [8]. Discovery of several bacteria capable of carrying out SND has generated considerable scientific interest in developing efficient biological nitrogen removal process in a single reaction vessel [7]. Examples of such organisms isolated from different sources include Agrobacterium sp. [9], Rhodococcus sp. [10], Alcaligenes faecalis [11], Diaphorobacter sp. [12], Bacillus subtilis [13], Bacillus methylotrophicus [14], Acinetobacter calcoaceticus [15], Marinobacter sp. [7], and Klebsiella pneumoniae [16]. Careful review of the literature shows that any bacterium capable of performing SND has not been isolated from slaughterhouse wastewater. It is further observed that there are gaps in understanding the role of microorganisms in the nitrogen removal processes occurring in abattoir wastewater. For example, Yilmaz et al. [8] reported that phosphate accumulating organisms (mainly Accumulibacter spp.) occurring in abattoir wastewater were responsible for the denitrification. However, microorganisms that reduced nitrate to nitrite, before Accumulibacter spp. could carry out denitrification from nitrite to nitrogen gas, could not be identified by the authors.

Thus, investigations on isolation of nitrifying and denitrifying bacteria from slaughterhouse wastewater, establishing their taxonomical identity, characterizing their metabolic patterns, and identifying their potential application in largescale nitrogen removal processes are necessary. In our previous study [17] we isolated a microbe from slaughterhouse wastewater and identified it as Achromobacter xylosoxidans. This bacterium, previously known as a clinical isolate was, for the first time, demonstrated to have nitrification activity. Interestingly, anaerobic denitrification, a property which is regarded as an intrinsic characteristic of the Achromobacter genus, was conserved. In continual pursuance of our search for novel nitrifiers/denitrifiers, the present paper describes the isolation of a new nitrifying-denitrifying bacterium capable of performing SND from wastewater emanating from a small-size rural slaughterhouse in India. This communication further reports its taxonomical identification, nitrogen removal pathway characterization, and kinetics of substrate utilization and growth.

\section{Materials and Methods}

2.1. Seed Acclimatization. Sludge collected from the pond discharging wastes of $\mathrm{M} / \mathrm{s}$ Mokami Slaughterhouse situated in Nazira, South 24 Parganas, West Bengal, India, was acclimatized to the laboratory conditions by cultivation in an aerated vessel for three months as described [17].

2.2. Isolation of the Bacterium and Development of Pure Culture. Ten predominant nitrifying bacteria were isolated from the seed acclimatization vessel as described [17]. Nitrification activities and preliminary taxonomic characterization of the isolates are presented as Supplementary File 1 in Supplementary Material available online at http://dx.doi.org/10.1155/2014/436056. Amongst them, the bacterium showing maximum nitrification activity (strain R31) was selected for further studies.

2.3. Molecular Phylogenetic Analysis of Strain R31. Extraction of DNA, amplification by polymerase chain reaction (PCR), and sequencing of the 16S rRNA gene were outsourced to Scigenome Labs, Kochi, India. DNA was extracted from the liquid culture of R31 grown in Luria broth following Sambrook et al. [19]. Amplification of the 16S rRNA gene of strain R31 was done with forward primer 27F (5'-AGA GTT TGA TCM TGG CTC AG- $\left.3^{\prime}\right)$ and reverse primer 1492R ( $5^{\prime}$-GGT TAC CTT GTT ACG ACT T-3 ${ }^{\prime}$ ) [20]. PCR was performed in a $50 \mu \mathrm{L}$ reaction mixture containing $5 \mu \mathrm{L}$ of 10x PCR buffer with $1.5 \mathrm{mM} \mathrm{MgCl}_{2}, 4 \mu \mathrm{L}$ of $10 \mathrm{mM} \mathrm{dNTP}$, 50 pmol of each oligonucleotide primers, and $1 \mu \mathrm{L}$ of $3 \mathrm{U}$ Taq DNA polymerase. The conditions of PCR were initial denaturation of $5 \mathrm{~min}$ at $94^{\circ} \mathrm{C}$, subsequently 30 incubation cycles each comprising 30 seconds denaturation at $94^{\circ} \mathrm{C}, 45 \mathrm{sec}$ annealing at $57^{\circ} \mathrm{C}, 1.5 \mathrm{~min}$ elongation at $72^{\circ} \mathrm{C}$, and a final 7 min elongation at $72^{\circ} \mathrm{C}$. The amplicon was electrophoresed in a $1 \%$ agarose gel and visualized under UV light. Next, the amplicon was purified using Nucleospin purification column (Macherey-Nagel, Germany). The amplicon was sequenced using an Applied Biosystems (USA) ABi 3730XL Genetic Analyzer. The PCR primers used for amplification were applied for sequencing the amplicon. Phylogenetic analysis of the $16 \mathrm{~S}$ rRNA gene sequence was done according to Kundu et al. [17].

2.4. Fatty Acid Methyl Ester (FAME) Analysis of Strain R31. FAME analysis of the isolate was outsourced to the Microbial Type Culture Collection and Gene Bank (MTCC), Institute of Microbial Technology, Chandigarh, India. Analysis was done using standard gas chromatography and applying the Sherlock MIS system.

2.5. Determination of Physiological Characteristics of Strain R31. Physiological characteristics of the strain were determined following the Bergey's manual [21]. Presence of flagella, anaerobic growth, sodium chloride tolerance, aesculin hydrolysis, indole production, catalase activity, gelatin liquefaction, Tween 80 hydrolysis, Simmons citrate utilization, deoxyribonuclease activity, Voges-Proskauer test, methyl red test, starch hydrolysis, $\beta$-galactosidase activity, urease test, and tyrosine hydrolysis were carried out following the methods described in Kundu et al. [17]. Nitrate reduction test was performed to determine whether the isolate (R31) elaborated the enzymes nitrate reductase and nitrite reductase. These two enzymes catalyze two reactions required for converting nitrate to the end product, nitrogen gas. Aliquot from a pure culture of the isolate R31 was aseptically inoculated to a sterile tube containing nitrate broth with an inverted Durham's tube. The inoculated tube was incubated at $37^{\circ} \mathrm{C}$ for 24 hours. Finally the reductions of nitrate and nitrite were ascertained by addition of naphthylamine and sulphanilic acid solutions to the nitrate broth followed by adding a small amount of zinc dust [22]. Acid production from various carbohydrates was done following Hinz et al. [23] and utilization of sole carbon, 
nitrogen, and amino acids was done according to Gutnick et al. [24] while growth in various media, different temperatures, and $\mathrm{pH}$ as well as testing of antibiotic resistance and susceptibility were done in accordance with standard procedures as follows. To determine the optimum temperature and $\mathrm{pH}$ for growth, the isolate was cultured in Luria-Bertani medium and incubated at $37^{\circ} \mathrm{C}$ with shaking $(100 \mathrm{rpm})$ for 48 hours. Bacterial growth was confirmed by measuring the optical density of the culture at $600 \mathrm{~nm}$. Susceptibility to antibiotics was determined by the routine agar-diffusion plate technique using disks impregnated with following antibiotics: vancomycin $(30 \mu \mathrm{g})$, lincomycin $(15 \mu \mathrm{g})$, kanamycin $(30 \mu \mathrm{g})$, neomycin $(30 \mu \mathrm{g})$, oleandomycin $(15 \mu \mathrm{g})$, ampicillin $(10 \mu \mathrm{g})$, benzylpenicillin (10 units), streptomycin $(10 \mu \mathrm{g})$, polymyxin B (300 units), gentamicin $(50 \mu \mathrm{g})$, tetracycline $(30 \mu \mathrm{g})$, carbenicillin $(100 \mu \mathrm{g})$, and chloramphenicol $(30 \mu \mathrm{g})$. Lysine and arginine decarboxylase activities were measured following Møller [25], whilst production of flexirubin pigment was tested according to Fautz and Reichenbach [26]. Hydrogen sulphide production was detected by visualizing the blackening of SIM medium [27]. All tests were done thrice in triplicate sets.

2.6. Carbon Oxidation and Ammonium Stabilization by Strain R31. Carbon oxidation and ammonium stabilization were assessed in batch cultures by cultivating strain $\mathrm{R} 31$ in a basal medium (all units g/L): $\mathrm{K}_{2} \mathrm{HPO}_{4} 14 ; \mathrm{KH}_{2} \mathrm{PO}_{4}$ 6; $\mathrm{MgSO}_{4} \cdot 7 \mathrm{H}_{2} \mathrm{O} 0.2$; trace mineral solution $2 \mathrm{~mL}$; $\mathrm{pH}$ (at $25^{\circ} \mathrm{C}$ ) $=7 \pm 0.2$. The trace mineral solution consisted of (all units g/L), EDTA 0.01; $\mathrm{ZnSO}_{4} \cdot 7 \mathrm{H}_{2} \mathrm{O} 0.0001 ; \mathrm{CaCl}_{2} \cdot 2 \mathrm{H}_{2} \mathrm{O}$ $0.1 ; \mathrm{MnCl}_{2} \cdot 2 \mathrm{H}_{2} \mathrm{O} 0.008 ; \mathrm{FeCl}_{3} \cdot 6 \mathrm{H}_{2} \mathrm{O} 0.71 ;\left(\mathrm{NH}_{4}\right)_{6} \mathrm{Mo}_{7} \mathrm{O}_{24}$ $0.00011 ; \mathrm{CuSO}_{4} \cdot 5 \mathrm{H}_{2} \mathrm{O}$ 0.0001; $\mathrm{CoCl}_{2} \cdot 6 \mathrm{H}_{2} \mathrm{O}$ 0.2. The carbon (glucose) concentration was $1.251 \mathrm{~g} / \mathrm{L}$ (carbon substrate $500 \mathrm{mg} / \mathrm{L}$ ) while nitrogen (ammonium chloride) was $0.191 \mathrm{~g} / \mathrm{L}$ (nitrogen substrate $50 \mathrm{mg} / \mathrm{L}$ ) forming $\mathrm{C} / \mathrm{N}$ ratio $(\mathrm{w} / \mathrm{w})$ of 10 . The sterilized media were inoculated with $1 \%$ $(\mathrm{v} / \mathrm{v})$ of the isolate and incubated at $37^{\circ} \mathrm{C}$ with shaking $(100 \mathrm{rpm})$ for $48 \mathrm{~h}$. Aliquots were removed from each Erlenmeyer flask at four hour intervals and growth was recorded by measuring $\mathrm{OD}_{600}$. Next, the liquid was centrifuged at $10,000 \mathrm{rpm}$ for 10 minutes and the supernatant was analyzed for COD (by closed reflux method using dichromate), ammonia, nitrite, and nitrate nitrogen by using an expandable ion electrode analyzer (Orion EA 940, Thermo Fisher Scientific, USA). Medium pH was measured using Cyberscan $510 \mathrm{pH}$ meter (Eutech Instruments, Singapore). Hydroxylamine was measured spectrophotometrically according to Frear and Burrell [28]. Experiments were done thrice in triplicate sets.

2.7. Influence of Carbon and Nitrogen Substrates on Nitrogen Removal by Strain R31. Effect of different types of carbon and nitrogen substrates and $\mathrm{C} / \mathrm{N}$ ratios on nitrogen removal is an important consideration in wastewater treatment. So, the influence of the nature of substrates and their relative concentrations on nitrogen removal ability of isolate R31 was investigated through batch experiments.

2.7.1. Carbon Substrates. From a survey of literature $[7,9,11-$ $15,29-33$ ] on the use of various carbon sources for bacteria carrying out SND, the most common substrates applied by other investigators appeared to be glucose, sodium succinate, sodium acetate, and sodium citrate. The influence of various carbon substrates was considered at constant ammonia nitrogen concentration of $50 \mathrm{mg} / \mathrm{L}$ and $\mathrm{C} / \mathrm{N}$ ratio of 10.0 . Glucose $(1.251 \mathrm{~g} / \mathrm{L})$, sodium succinate $(1.688 \mathrm{~g} / \mathrm{L})$, sodium acetate $(1.709 \mathrm{~g} / \mathrm{L})$, and trisodium citrate $(1.792 \mathrm{~g} / \mathrm{L})$ were used as different carbon substrates in the basal medium described in Section 2.6 taking into account the fixed ammonia nitrogen concentration and the corresponding constant $\mathrm{C} / \mathrm{N}$ ratio.

2.7.2. Nitrogen Substrates. Sodium nitrite $(0.303 \mathrm{~g} / \mathrm{L})$ and sodium nitrate $(0.303 \mathrm{~g} / \mathrm{L})$ were used in place of ammonium chloride in the basal medium described in Section 2.6 to ascertain the denitrification pathway of R31. The carbon substrate concentration and $\mathrm{C} / \mathrm{N}$ ratio were fixed at $500 \mathrm{mg} / \mathrm{L}$ and 10.0 , respectively.

2.7.3. $\mathrm{C} / \mathrm{N}$ Ratios. The influence of various $\mathrm{C} / \mathrm{N}$ ratios, namely, 5,10 , and 20 , on heterotrophic nitrification-aerobic denitrification by strain R31 was considered at constant ammonium nitrogen concentration of $50 \mathrm{mg} / \mathrm{L}$. The $\mathrm{C} / \mathrm{N}$ ratio was fixed by adjusting the amount of the carbon substrate. Thus, the amounts of glucose used were $0.625 \mathrm{~g} / \mathrm{L}(\mathrm{C} / \mathrm{N}$ $=5), 1.251 \mathrm{~g} / \mathrm{L}(\mathrm{C} / \mathrm{N}=10)$, and $2.502 \mathrm{~g} / \mathrm{L}(\mathrm{C} / \mathrm{N}=20)$. Each flask containing sterilized media was inoculated with the isolate $(1 \% \mathrm{v} / \mathrm{v})$ and incubated at $37^{\circ} \mathrm{C}$ with shaking $(100 \mathrm{rpm})$ for $48 \mathrm{~h}$. Aliquots were removed from each Erlenmeyer flask at four hour intervals and growth was recorded by measuring $\mathrm{OD}_{600}$. The liquid was centrifuged at $10,000 \mathrm{rpm}$ for 10 minutes and analyzed for ammonia nitrogen. All experiments were done thrice in triplicate sets.

2.8. Evaluation of Kinetic Parameters. To study simultaneous carbon oxidation, nitrification, and denitrification kinetics, experiments were carried out in four different sets; wherein each set consisted of twelve Erlenmeyer flasks. The $\mathrm{C} / \mathrm{N}$ ratio in each flask was maintained at 10.0 with appropriate amounts of glucose (carbon substrate) and ammonium chloride (nitrogen substrate). All flasks containing sterilized basal media were inoculated with the isolate $(1 \% \mathrm{v} / \mathrm{v})$ and incubated at $37^{\circ} \mathrm{C}$ with shaking $(100 \mathrm{rpm})$ for $48 \mathrm{~h}$. One flask from each set was removed from the shaker every four hours. The culture was centrifuged at 10,000 rpm for 10 minutes and the supernatant was analyzed for COD, ammonia nitrogen, nitrate nitrogen, $\mathrm{pH}$, and MLVSS (mixed liquor volatile suspended solids), which was measured gravimetrically in a muffle furnace at $550 \pm 50^{\circ} \mathrm{C}$ ). Experiments were done thrice.

2.8.1. Kinetics of Substrate Removal and Growth. Estimation of the kinetic constants for carbon and ammonia utilization, such as half saturation concentration $\left(K_{s}\right)$ and maximum substrate utilization rate $(k)$, as well as determination of the growth kinetic constants such as yield coefficient $(Y)$ and the endogenous decay coefficient $\left(K_{d}\right)$ were done by applying Lawrence and McCarty's modified Monod equation [34]. The results so obtained were fitted in to a straight line in accordance with the Lineweaver-Burk plot for determination of the kinetic constants. 


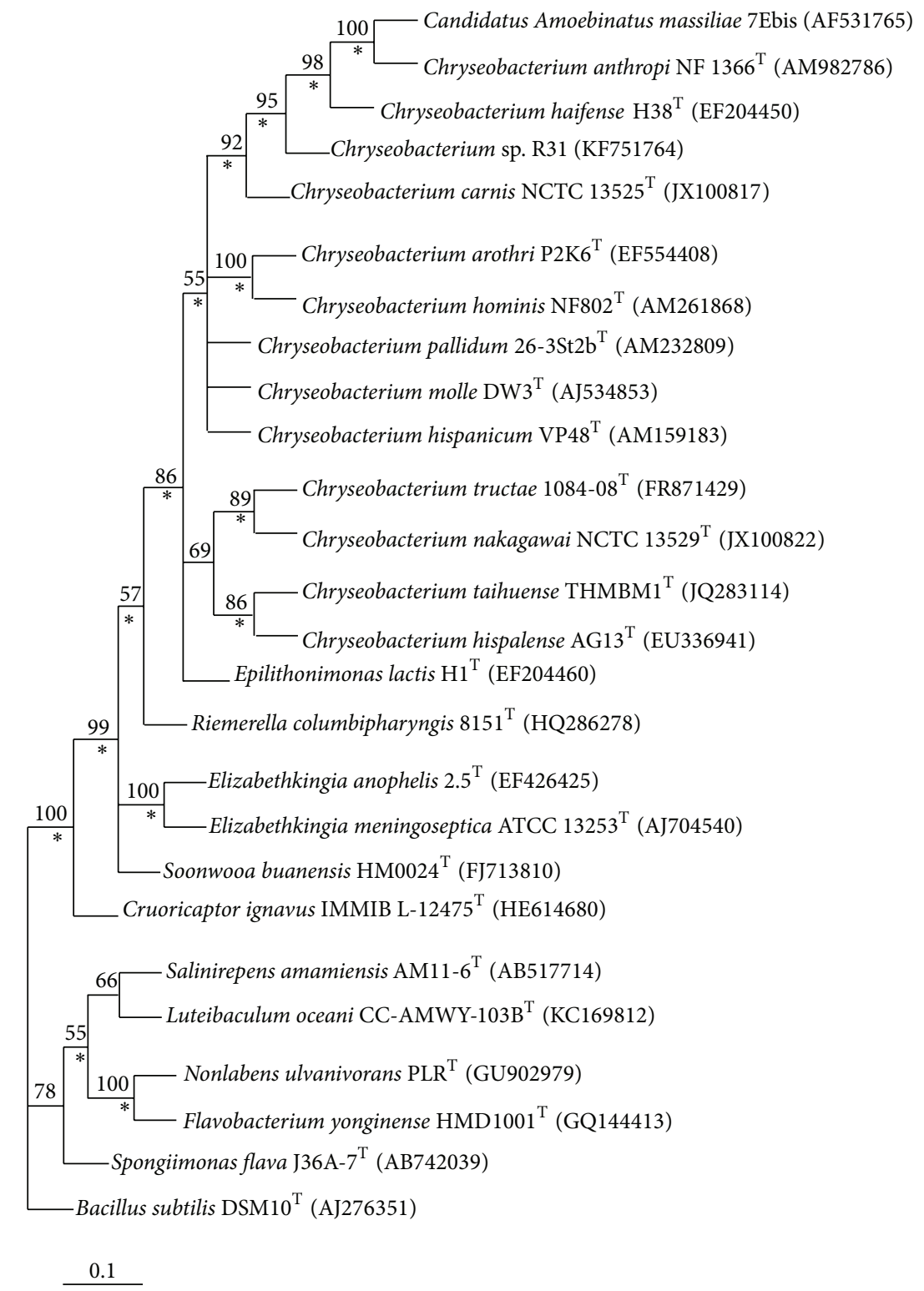

FIGURE 1: Unrooted phylogenetic tree obtained by the neighbor-joining (NJ) method based on 16S rRNA gene sequences depicting the position of strain Chryseobacterium sp. R31 amongst its phylogenetic neighbors. Numbers at nodes designate levels of bootstrap support (\%) based on a NJ analysis of 1000 resampled datasets; only values higher than 50\% are displayed. Asterisks denote branches that were obtained using the maximum parsimony and maximum likelihood algorithms. NCBI accession numbers are provided in parentheses. Bar $=0.1$ nucleotide substitutions per site. The sequence of Bacillus subtilis DSM 10 (AJ276351) was applied as an outgroup.

\section{Results and Discussion}

3.1. Basic Taxonomical Identification of Strain R31. The physiological characteristics of isolate R31 are listed in Supplementary File 2. Small, circular colonies with entire edges were observed when R31 was grown on nutrient agar plates. The colonies were glossy, raised, and yellowish-golden in color. On the basis of nucleotide homology and phylogenetic analysis, the isolate was shown to be significantly similar to Chryseobacterium haifense. Identity analysis on the EZ taxon server [35] revealed that the $16 \mathrm{~S}$ rRNA gene sequence had the closest similarity $(98.25 \%)$ to the gene sequence of the type strain of Chryseobacterium haifense (Supplementary File 3). The phylogenetic position of the isolate (R31) having NCBI Genbank accession number KF751764 is shown in the dendogram (Figure 1). Strain R31 emerged as a distinctive phylogenetic line from the cluster containing the type of strains of Chryseobacterium species shown in Supplementary File 3. This differentiation was corroborated by considerable branch length and a high bootstrap value (95\%). The phylogenetic position of strain R31 was further supported by the maximum parsimony (MP) and maximum likelihood (ML) analyses. An analogous delineation of the strain was found applying the MP and ML algorithms, which was again 
confirmed by high bootstrap values (70\% for MP and $98 \%$ for ML) and significant branch lengths. The result of the fatty acid methyl ester (FAME) analysis is shown in Supplementary File 4 . The predominant cellular fatty acids of isolate R31 were $15: 0$ iso (40.40\%), $15: 0$ anteiso (19.44\%), and 17:0 iso 3-OH (11.13\%) which closely matched those of Chryseobacterium haifense $^{T}: 15: 0$ iso (41.6\%), 15:0 anteiso (16.6\%), and 17:0 iso 3$\mathrm{OH}(10.3 \%)$ [36]. In the nitrate reduction test, gas formation was observed in Durham's tube indicating that the isolate R31 had the ability to convert nitrate to nitrite and then to nitrogen gas. The isolate (R31) was found positive for both nitrate reductase and nitrite reductase. Similar conclusions were drawn by Fernández et al. [37].

A number of physiological characteristics corresponded with the standard species description of $C$. haifense such as having Gram-negative reaction, being nonmotile without any flagella, being obligately aerobic, having temperature ranges of growth, having growth at $4^{\circ} \mathrm{C}$, having $\mathrm{NaCl}$ requirements for growth, being oxidase positive, being urease negative, being lysine decarboxylase negative, being aesculin and gelatin hydrolysis positive, and being flexirubin production negative. On the other hand the physiological traits of strain R31 that did not agree the standard species description of C. haifense were having acid production from carbohydrates, being catalase negative, being nitrate reduction positive, being $\beta$-galactosidase negative, being indole production negative, and being $\mathrm{H}_{2} \mathrm{~S}$ production positive. Strain R31 may be a new member of the Chryseobacterium genus and further confirmation can be made through DNA-DNA hybridization tests.

\subsection{Simultaneous COD and Nitrogen Removal by Strain R31}

3.2.1. Carbon Oxidation and Ammonium Stabilization by Strain R31. Figure 2 shows the profile of COD removal with respect to the time of contact. After $48 \mathrm{~h}, 95.54 \%$ of COD was removed from the initial concentration of $583.0 \mathrm{mg} / \mathrm{L}$, indicating heterotrophic nutritional characteristic of isolate R31. Stabilization of the utilizable component of the basal medium within the reaction period was indicated by the asymptotic nature of the curve after $48 \mathrm{~h}$. Growth kinetics corresponding to carbon oxidation is also shown in Figure 2. The lag phase lasted for approximately $4 \mathrm{~h}$ following which isolate R31 grew exponentially for $30 \mathrm{~h}$. Highest biomass production was observed around $48 \mathrm{~h}$ following which the microorganism attained the stationary phase of growth. Yang et al. [13] demonstrated growth of heterotrophic nitrifyingdenitrifying Bacillus subtilis A1 and the nitrogen removal process consumed most of the organic substrates in the media, yielding COD removal efficiencies of $71.0 \pm 0.5 \%$, $67.1 \pm 0 \%, 64.5 \pm 1.5 \%$, and $63.9 \pm 1.8 \%$ for acetate, glucose, citrate, and succinate, respectively. Khardenavis et al. [12] attained COD removal of 85-93\% using Diaphorobacter sp. These values were lower than that obtained in this study.

The profile of ammoniacal nitrogen utilization by isolate R31 with relation to time is also shown in Figure 3. After a contact period of $48 \mathrm{~h}, 95.87 \%$ of $\mathrm{NH}_{4}^{+}-\mathrm{N}$ was consumed demonstrating the heterotrophic nitrification ability of

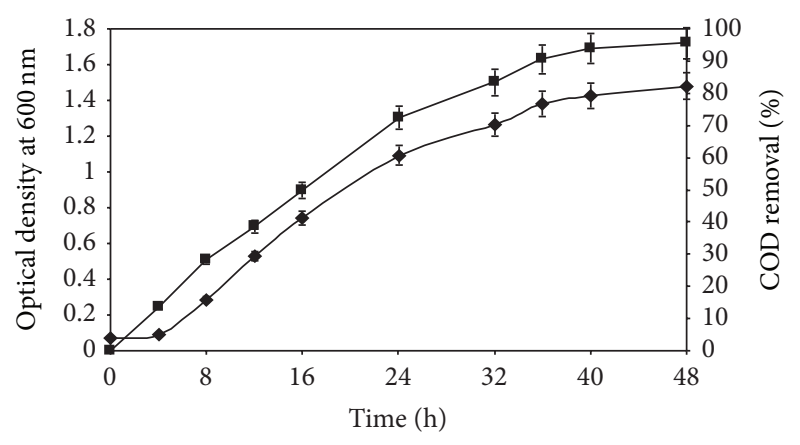

FIGURE 2: Time profile of carbon oxidation and growth of Chryseobacterium sp. R31. Growth (filled diamonds) and COD removal (\%) (filled squares). Error bars represent one SD $(n=9)$.

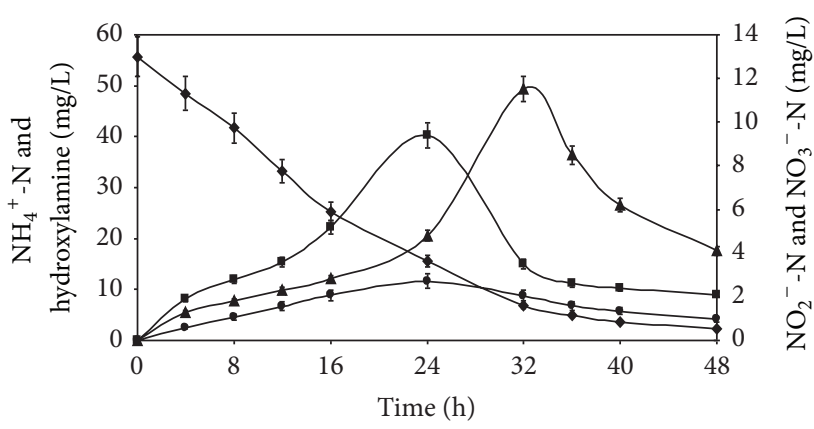

Figure 3: Time profile of ammonium oxidation by Chryseobacterium sp. R31. Ammonium nitrogen (filled diamonds), nitrite nitrogen (filled squares), nitrate nitrogen (filled triangles), and hydroxylamine (filled circle). Error bars represent one SD $(n=9)$.

the isolate. Figure 3 further depicts that the initial ammonia utilization rate was high and maximum stabilization of ammonium in solution was attained within $32 \mathrm{~h}$, after which the utilization declined and ammonium was removed marginally. Exhaustion of ammonium led to reduced availability of the nitrogen substrate to the microorganism. Figure 3 also represents the corresponding nitrite nitrogen $\left(\mathrm{NO}_{2}{ }^{-}-\mathrm{N}\right)$ and nitrate nitrogen $\left(\mathrm{NO}_{3}{ }^{-}-\mathrm{N}\right)$ concentrations with respect to time. This figure shows that ammonium was substantially converted to nitrite and, after a reaction period of $24 \mathrm{~h}$, the nitrite level in the reactor was maximum corresponding to $71.99 \%$ ammonium utilization. Nitrate concentration initially increased with time confirming heterotrophic nitrification by strain R31. Nitrate concentration reached its peak value at $32 \mathrm{~h}$ when $87.79 \%$ of ammonium was consumed. The decrease in nitrate concentration after reaching a peak value ascertained the denitrification process. Nitrate was utilized by the isolate after ammonium was exhausted. Hydroxylamine was detected in reduced amounts possibly due to the unstable nature of hydroxylamine and rapid transformation to the next intermediate, nitrite [14]. Simultaneous utilization of organic matter and ammonia degradation indicated R31 to be competent of heterotrophic nitrification as well as aerobic denitrification. Hydroxylamine, nitrite, and nitrate accumulation occurred 


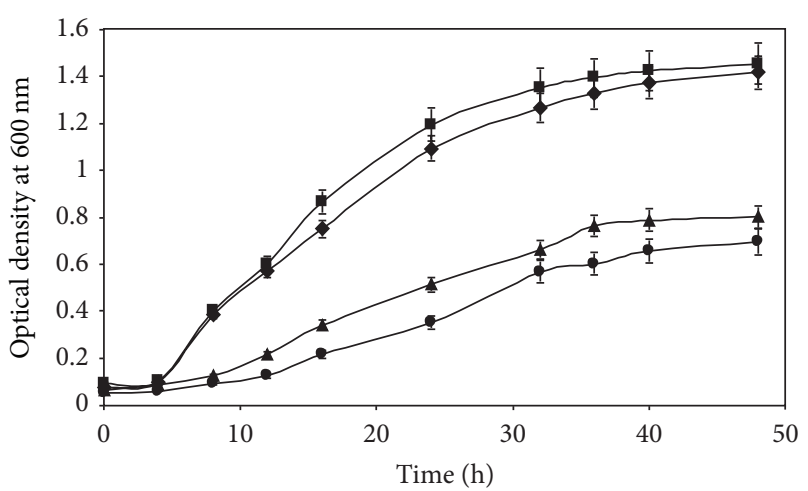

(a)

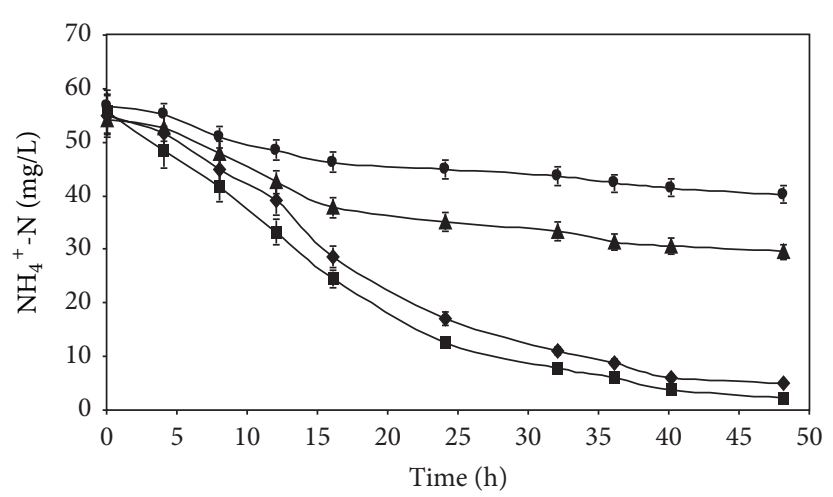

(b)

Figure 4: (a) Influence of various carbon substrates on growth of Chryseobacterium sp. R31. Sodium succinate (filled diamonds), glucose (filled squares), trisodium citrate (filled triangles), and sodium acetate (filled circles). Error bars represent one SD ( $n=9)$ ). (b) Influence of various carbon substrates on ammonium removal by Chryseobacterium sp. R31. Sodium succinate (filled diamonds), glucose (filled squares), trisodium citrate (filled triangles), and sodium acetate (filled circles). Error bars represent one SD $(n=9)$.

with the decrease of ammonia nitrogen. The concentrations of the three intermediates were low, thus ensuring nitrogen removal. The profile of hydroxylamine, nitrite, and nitrate formation was similar to that observed during SND processes occurring in Agrobacterium sp. [9] as well as Klebsiella pneumonia [16]. The amount of ammonium removed $(95.87 \%$ in $48 \mathrm{~h}$ ) was higher than that striped off by Bacillus subtilis $(58.4 \pm 4.3 \%$ in $60 \mathrm{~h})$ [13], Bacillus methylotrophicus $(51.03 \%$ in $54 \mathrm{~h}$ ) [14], and Marinobacter sp. F6 (48.62\%) [7]. The ammonium utilization rate $(1.15 \mathrm{mg} / \mathrm{L} / \mathrm{h})$ was similar to that obtained for Pseudomonas alcaligenes sp. AS-1 (1.15 mg/L/h) [10] and higher than the corresponding value of Bacillus sp. LY $(0.43 \mathrm{mg} / \mathrm{L} / \mathrm{h})[10]$.

\subsubsection{Influence of Carbon Substrates on Nitrogen Removal by} Strain R31. The influence of various carbon substrates on growth of strain R31 and ammonium stabilization by the isolate is represented in Figures 4(a) and 4(b), respectively. The plot depicts abundant growth when glucose or succinate was used; whereas lesser biomass was formed with citrate and acetate as substrates indicating that these carbon sources were not utilizable by the isolate. Within $48 \mathrm{~h}, 95.87 \%$ and $91.07 \%$ of $\mathrm{NH}_{4}{ }^{+}-\mathrm{N}$ were removed in the presence of glucose and sodium succinate, respectively, whilst reduced nitrification occurred in the presence of citrate and acetate. It was also inferred that simultaneous COD removal, nitrification, and denitrification would not be totally achieved in wastewater containing these substrates. Glucose and sodium succinate were superior carbon substrates for nitrogen removal by Marinobacter sp. [7] and Bacillus methylotrophicus [14] whilst citrate and acetate were inferior substrates, analogous to our results. On the other hand, citrate and acetate proved to be better substrates for nitrogen removal by A. faecalis [11]. The four substrates glucose, acetate, citrate, and succinate removed nitrogen with equal efficiency during simultaneous nitrification-denitrification by Bacillus subtilis [13].

A specific membrane transporter, citrate lyase activity, and oxaloacetate decarboxylase activity are required for bacterial citrate utilization [38]. There are two routes for the metabolic interconversion of acetate and acetylCoA: acetyl-CoA synthetase pathway and acetate kinasephosphotransacetylase pathway. Growth on acetate further entails the glyoxylate shunt, thus bypassing the decarboxylation steps of the tricarboxylic acid cycle. This, in turn, needs two enzymes, isocitrate lyase and malate synthase [39]. It appeared that the metabolic pathways and/or enzymes required for citrate and acetate utilization were either partially inactive or repressed when isolate R31 was fed with citrate and acetate. Succinate was used as efficiently as glucose for growth and ammonium stabilization by isolate R31. Succinate is a bifunctional substrate of succinate dehydrogenase, an enzyme that is required in both the TCA cycle and the electron transport chain, coupling carbon flow to ATP synthesis [40].

\subsubsection{Influence of Nitrogen Substrates on Nitrogen Removal} by Strain R31. The influence of various nitrogen substrates on growth of isolate R31 and nitrogen removal is shown in Figures 5(a) and 5(b), respectively. It is evident from the figures that similar growth was attained with ammonium chloride, nitrate, and nitrite as substrates. Nitrogen removal was nearly alike for all three substrates. Thus, the isolate was capable of utilizing ammonium, nitrate, and nitrite as nitrogen substrates and heterotrophic nitrification-aerobic denitrification was independent of the nature of the nitrogen substrate. Growth with nitrite was sufficient, and $75 \%$ nitrite was utilized. It appeared that the enzymes required for ammonium utilization such as ammonium monooxygenase and hydroxylamine oxidoreductase as well as nitrite/nitrate reductase required for nitrate utilization were all active when the organism was fed with these substrates. This experiment further confirmed the nitrification and denitrification ability of the isolate. Aerobic denitrification occurring during ammonium removal by R31 demonstrated by utilization of both nitrate and nitrite was similar to the process occurring in Agrobacterium strain LAD9 as reported by Chen and $\mathrm{Ni}$ 


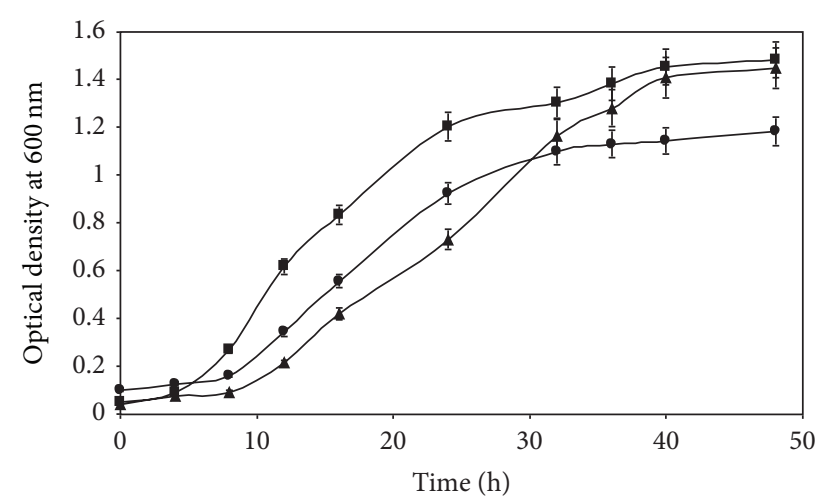

(a)

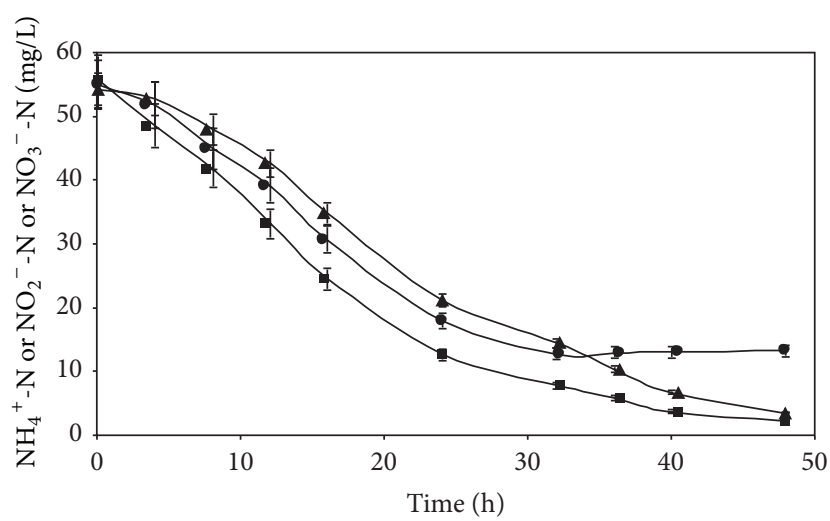

(b)

Figure 5: (a) Influence of various nitrogen substrates on growth of Chryseobacterium sp. R31. Ammonium chloride (filled squares), sodium nitrate (filled triangles), and sodium nitrite (filled circles). Error bars represent one SD $(n=9)$. (b) Influence of various nitrogen substrates on nitrogen removal by Chryseobacterium sp. R31. Ammonium chloride (filled squares), sodium nitrate (filled triangles), and sodium nitrite (filled circles). Error bars represent one SD $(n=9)$.

[9]. The nitrate removal rate was $1.0 \mathrm{mg} / \mathrm{L} / \mathrm{h}$ which is higher than that recorded for Rhodococcus $(0.93 \mathrm{mg} / \mathrm{L} / \mathrm{h})$ as reported by Chen et al. [10]. Aerobic denitrifiers utilize nitrite by intracellular assimilation or extracellular reduction pathways. Similar to the observations for Klebsiella pneumoniae [16], concomitant cell density increase was noted in our experiments along with consumption of nitrite indicating that extracellular reduction had occurred. Aerobic denitrification ability of strain R31 was confirmed by the positive results obtained in the nitrate and nitrite reductase assays (these enzyme activities were absent in the type of strain of $C$. haifense).

Two pathways are implicated in the simultaneous nitrification and denitrification processes, the first through nitrite and nitrate and the second via hydroxylamine [41]. Thiosphaera pantotropha [32], Bacillus subtilis [13], Agrobacterium sp. [9], Rhodococcus sp. [10], K. pneumoniae [16], and Marinobacter sp. [7] possess a complete nitrification and denitrification pathway $\left(\mathrm{NH}_{4}{ }^{+}-\mathrm{NH}_{2} \mathrm{OH}-\mathrm{NO}_{2}{ }^{-}-\mathrm{NO}_{3}{ }^{-}-\mathrm{N}_{2} \mathrm{O}-\right.$ $\mathrm{N}_{2}$ ). Contrastingly, neither nitrite nor nitrate was detected as intermediates in Alcaligenes faecalis [11] and Acinetobacter calcoaceticus [15]. Furthermore, nitrite or nitrate reductase activities were not detected in these two bacteria. Denitrification in A. faecalis and A. calcoaceticus occurs through hydroxylamine, not requiring nitrite or nitrate $\left(\mathrm{NH}_{4}^{+}{ }_{-}\right.$ $\mathrm{NH}_{2} \mathrm{OH}-\mathrm{N}_{2} \mathrm{O}-\mathrm{N}_{2}$ ). Results as described in this section, in relation to the reports of previous workers, indicate that Chryseobacterium sp. R31 has a complete nitrification and denitrification pathway. Conventionally, denitrification occurs under anoxic conditions but strain R31 is obligately aerobic. Microorganisms capable of SND possess respiratory and fermentative types of metabolism. Bacteria belonging to the genera Agrobacterium [42], Rhodococcus [43], Alcaligenes [44], Acinetobacter [45], and Marinobacter [46] are obligately aerobic. Bacteria of the Bacillus genus [47] are aerobic, which may be strict or facultative while the genus Klebsiella [48] comprises facultative anaerobic bacteria.
3.2.4. Influence of Different $C / N$ ratios on Growth and Ammonium Removal by Strain R31. Figures 6(a) and 6(b) show that, at $\mathrm{C} / \mathrm{N}$ ratio of 10 , the growth rate of isolate $\mathrm{R} 31$ was the highest and maximum ammonia nitrogen was removed (95.87\%) within $48 \mathrm{~h}$. Figure 6(b) also demonstrates that, after $48 \mathrm{~h}$ of contact, $\mathrm{NH}_{4}{ }^{+}-\mathrm{N}$ utilization nearly ceased indicating exhaustion of the nutrient or inhibition of key enzyme(s). The $\mathrm{NH}_{4}{ }^{+}-\mathrm{N}$ utilization rate (Figure 6(b)) and growth (Figure $6(\mathrm{a})$ ) of strain $\mathrm{R} 31$ were found to be the higher at $\mathrm{C} / \mathrm{N}$ $=10$ in comparison to those achieved with $\mathrm{C} / \mathrm{N}$ ratios of 5 and 20. The rate of nitrogen removal at $\mathrm{C} / \mathrm{N}=10$ accelerated beyond $8 \mathrm{~h}$ and reached an equilibrium level after $40 \mathrm{~h}$. At $\mathrm{C} / \mathrm{N}$ ratio of 5 , the consumption of ammoniacal nitrogen practically stopped after $36 \mathrm{~h}$ of incubation, resulting in $63.11 \%$ removal. At $\mathrm{C} / \mathrm{N}=5$, heterotrophic nitrification could not be performed efficiently for residual $\mathrm{NH}_{4}{ }^{+}-\mathrm{N}$ beyond $20.25 \mathrm{mg} / \mathrm{L}$ after $36 \mathrm{~h}$, perhaps due to early exhaustion of the carbon source. On the other hand, at $\mathrm{C} / \mathrm{N}=10$, the growth curve shows that higher biomass was reached probably due to enhanced amounts of utilizable $\mathrm{C}$ and $\mathrm{N}$ nutrients. At $\mathrm{C} / \mathrm{N}$ $=20$, the overall removal of $\mathrm{NH}_{4}{ }^{+}-\mathrm{N}$ was close to the value attained at $\mathrm{C} / \mathrm{N}=10$ but initial consumption was delayed by a time lag. Appreciable removal at this ratio ensued after $24 \mathrm{~h}$. Joo et al. [11] reported similar trend of ammoniacal nitrogen utilization by the heterotrophic nitrifier (Alcaligenes faecalis No. 4). Authors observed that, at lower $\mathrm{C} / \mathrm{N}$ ratio such as 5, 40\% unconsumed $\mathrm{NH}_{4}{ }^{+}-\mathrm{N}$ remained in the reactor due to dearth of the carbonaceous substrate. At $\mathrm{C} / \mathrm{N}$ ratio of 10 , authors noted that both carbon and $\mathrm{NH}_{4}{ }^{+}-\mathrm{N}$ levels decreased in a well-balanced fashion with respect to time along with appreciable amount of growth of the microorganism. For Bacillus subtilis A1, optimal C/N ratio was 6.0 and ammonium and acetate were consumed at a proportionate rate [13]. At $\mathrm{C} / \mathrm{N}=2$, the consumption of $\mathrm{NH}_{4}{ }^{+}-\mathrm{N}$ stopped because the carbon source was depleted. The $\mathrm{NH}_{4}{ }^{+}-\mathrm{N}$ removal efficiency was higher at $\mathrm{C} / \mathrm{N}=6$ and $\mathrm{C} / \mathrm{N}=12$ than at $\mathrm{C} / \mathrm{N}=2$ and $\mathrm{C} / \mathrm{N}$ $=26$ at $60 \mathrm{~h}$. 


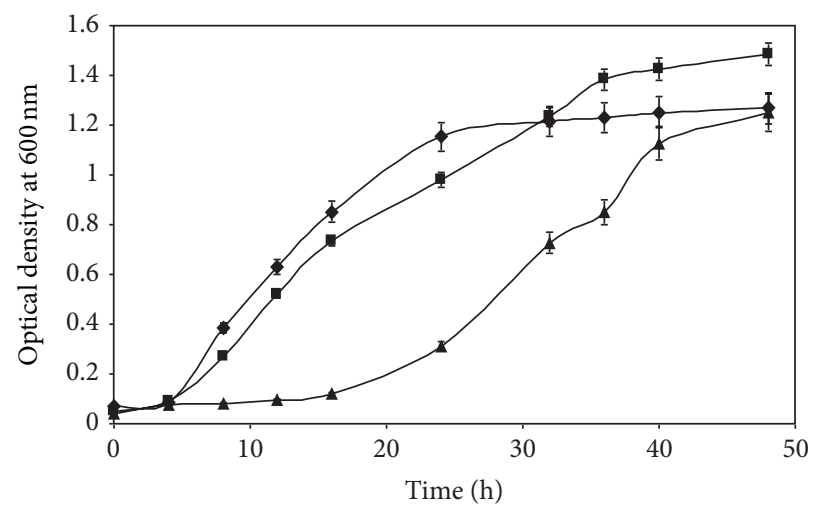

(a)

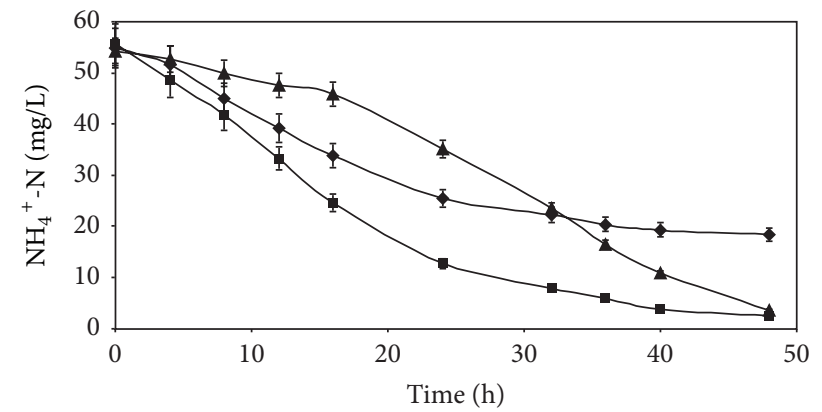

(b)

Figure 6: (a) Influence of different $\mathrm{C} / \mathrm{N}$ ratios on growth of Chryseobacterium sp. R31. C/N = 5 (filled diamonds), $\mathrm{C} / \mathrm{N}=10$ (filled squares), and $\mathrm{C} / \mathrm{N}=20$ (filled triangles). Error bars represent one $\mathrm{SD}(n=9)$. (b) Influence of different $\mathrm{C} / \mathrm{N}$ ratios on ammonium removal by Chryseobacterium sp. R31. $\mathrm{C} / \mathrm{N}=5$ (filled diamonds), $\mathrm{C} / \mathrm{N}=10$ (filled squares), and $\mathrm{C} / \mathrm{N}=20$ (filled triangles). Error bars represent one $\mathrm{SD}(n=9)$.

The optimal values of C/N ratios were 8.0-9.0 for Agrobacterium [9], and 15.0 for Bacillus sp. LY [10] and Marinobacter sp. [7]. Increasing the $\mathrm{C} / \mathrm{N}$ ratio enhanced nitrate removal rates of Pseudomonas putida, whereas nitrogen assimilation into the cell mass was not changed. The optimal $\mathrm{C} / \mathrm{N}$ ratio was 8 [33]. C/N ratio did not influence heterotrophic nitrification by Bacillus methylotrophicus [14]. In general, for a given $\mathrm{C} / \mathrm{N}$ range, an enhancement in organic carbon concentration resulted in increased denitrification efficiency of aerobic denitrifiers [7]. Our observations support this statement. Lower value of $\mathrm{C} / \mathrm{N}$ ratio is advantageous in wastewater treatment processes as operating costs can be reduced [9]. Considering this, nitrogen removal using Chryseobacterium sp. R31 may be more economical than Bacillus sp. LY and Marinobacter sp. and as cost-effective as A. faecalis. In light of the recommendations of Joo et al. [11], the $\mathrm{C} / \mathrm{N}$ ratio can be used as a criterion of control when considering ammonium removal in continuous culture by $\mathrm{R} 31$ and the addition of external carbon would be necessary in the treatment of highstrength ammonium wastewater at $\mathrm{C} / \mathrm{N}$ less than 10 .

3.2.5. Substrate Removal and Growth Kinetics of Simultaneous Carbon Oxidation, Nitrification, and Denitrification by Strain R31. Substrate removal kinetics for carbon oxidation, nitrification, and denitrification as well as growth kinetics for carbon oxidation, nitrification, and denitrification were studied applying Lawrence and McCarty's modified Monod equation [34]. The data fitted reasonably well following the Lineweaver-Burk equation (Figures 7(a)-7(f)). From these plots, $K_{s}, k, Y$, and $k_{d}$ were estimated as enumerated in Table 1. As shown in Table 1 , the values of the coefficients were similar to those obtained for the other slaughterhouse wastewater isolate, A. xylosoxidans [17], and those determined for aerobic-anoxic process for slaughterhouse wastewater [1]. Although belonging to different genera, the kinetics of substrate utilization displayed by the two isolates (A. xylosoxidans and Chryseobacterium sp.) was essentially similar. It may be noted that the $K_{s}$ values for carbon oxidation $(220.11 \mathrm{mg} / \mathrm{L})$ and nitrification $(2.19 \mathrm{mg} / \mathrm{L})$ obtained in this study were higher than those conventionally accepted for domestic wastewater (for comparison see Table 1). Enhanced values were attained due to the higher initial COD and $\mathrm{NH}_{4}{ }^{+}$$\mathrm{N}$ levels found in slaughterhouse wastewater compared to that present in domestic wastewater [18]. Values indicate that R31 had low affinity for carbonaceous substrate as well as for ammonia. The high $K_{s}$ value may be an effect of high substrate concentration [49]. The other kinetic coefficients $\left(k, Y\right.$, and $\left.k_{d}\right)$ for carbon oxidation and nitrification were, however, comparable to that reported for domestic 


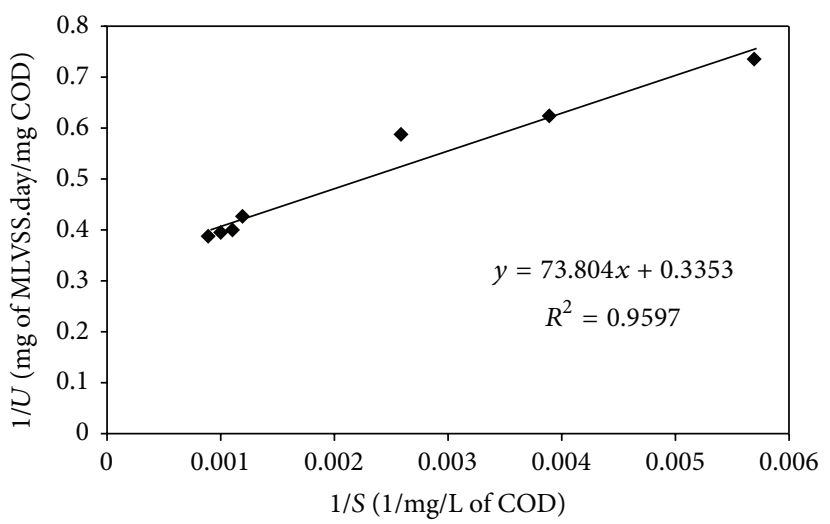

(a)

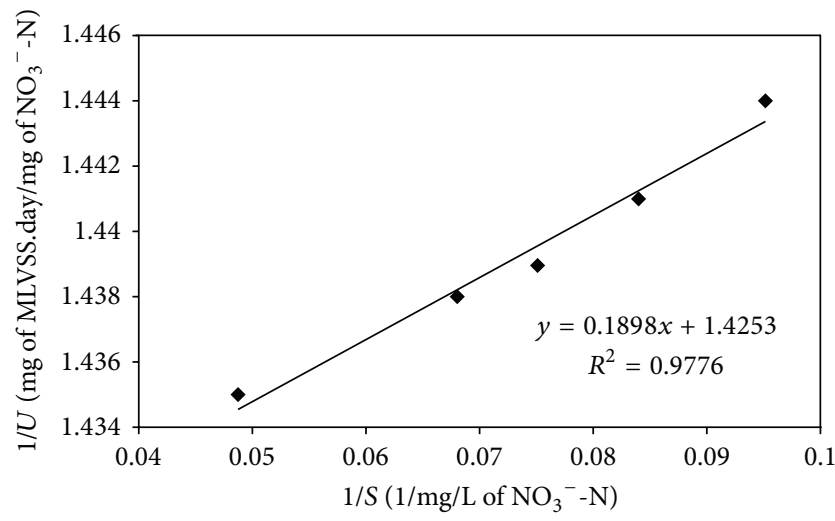

(c)

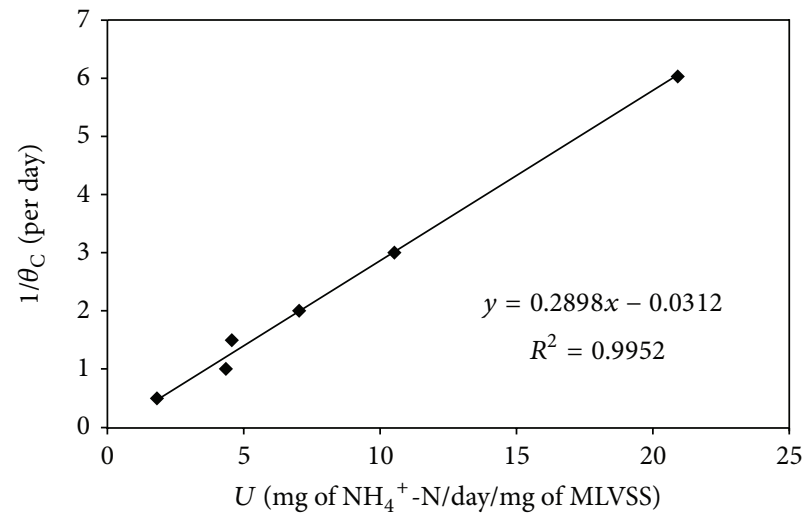

(e)

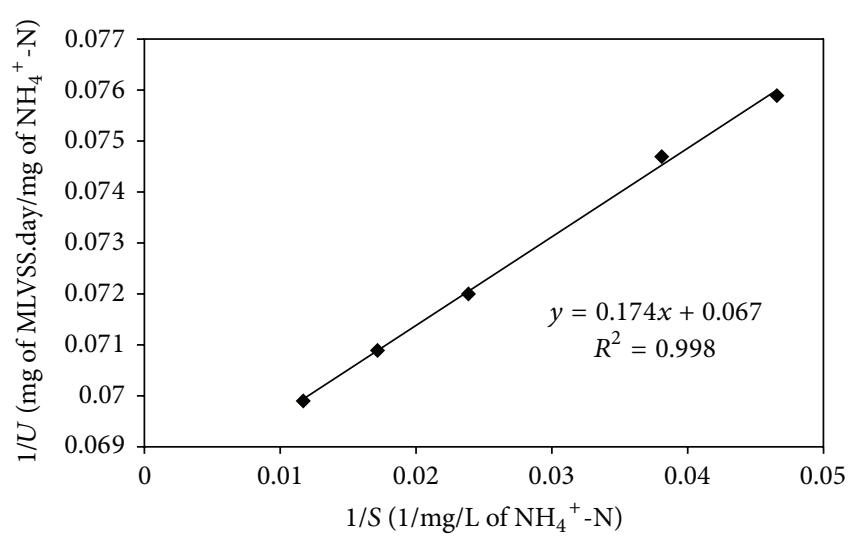

(b)

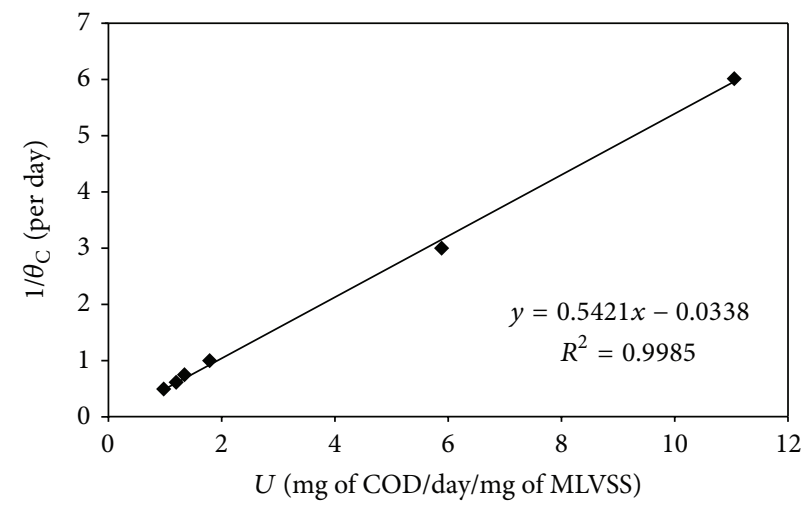

(d)

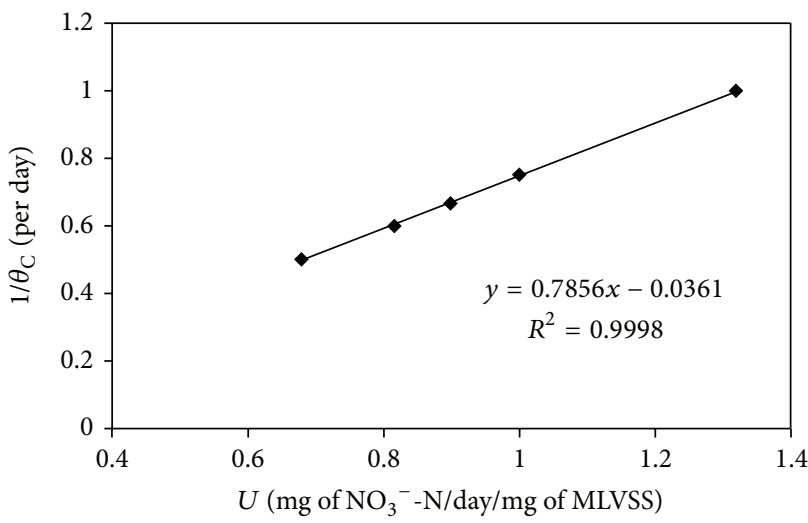

(f)

FIGURE 7: Lineweaver-Burk plot for determination of substrate utilization kinetic constants for (a) carbon oxidation, (b) nitrification, and (c) denitrification and growth kinetic constants for (d) carbon oxidation, (e) nitrification, and (f) denitrification by Chryseobacterium sp. R31. Each data point represents the mean value of nine determinations. Error is within one SD of the mean.

TABLE 1: Summarized values of kinetic coefficients obtained in the present study, our previous study [17], and domestic wastewater [18].

\begin{tabular}{|c|c|c|c|c|c|c|c|c|}
\hline \multirow[b]{2}{*}{ Kinetic coefficients } & \multicolumn{3}{|c|}{ Carbon oxidation } & \multicolumn{3}{|c|}{ Nitrification } & \multicolumn{2}{|c|}{ Denitrification } \\
\hline & $\begin{array}{c}\text { Present } \\
\text { study }\end{array}$ & $\begin{array}{l}\text { Kundu et } \\
\text { al. [17] }\end{array}$ & $\begin{array}{l}\text { Metcalf and } \\
\text { Eddy [18] }\end{array}$ & $\begin{array}{c}\text { Present } \\
\text { study }\end{array}$ & $\begin{array}{l}\text { Kundu et } \\
\text { al. [17] }\end{array}$ & $\begin{array}{l}\text { Metcalf and } \\
\text { Eddy [18] }\end{array}$ & $\begin{array}{l}\text { Present } \\
\text { study }\end{array}$ & $\begin{array}{l}\text { Metcalf and } \\
\text { Eddy [18] }\end{array}$ \\
\hline$k\left(\right.$ day $\left.^{-1}\right)$ & 2.98 & 2.24 & $2-10$ & 14.66 & 13.66 & $1-30$ & 0.70 & $0.23-2.88$ \\
\hline$K_{s}(\mathrm{mg} / \mathrm{L})$ & 220.11 & 232.0 & $25-100$ & 2.19 & 2.13 & $0.2-0.5$ & 0.13 & $0.06-0.20$ \\
\hline$Y(\mathrm{mg} / \mathrm{mg})$ & 0.54 & 0.44 & $0.4-0.8$ & 0.28 & 0.24 & $0.1-0.3$ & 0.78 & $0.4-0.9$ \\
\hline$k_{d}\left(\right.$ day $\left.^{-1}\right)$ & 0.03 & 0.06 & $0.025-0.075$ & 0.03 & 0.05 & $0.03-0.06$ & 0.03 & $0.04-0.08$ \\
\hline
\end{tabular}


wastewater [18]. For municipal and industrial wastewater, the coefficient values represent the net effect of microbial kinetics on the simultaneous degradation of a variety of different wastewater constituents. The kinetic coefficients determined for denitrification corroborated with the typical values obtained for domestic wastewater (for comparison see Table 1). The constants determined are suitable for COD and nitrogen removal, similar to the conclusions of Pala and Bölükbaş [50]. Authors reported that the Monod kinetic constants $\left(Y, k_{d}\right.$, and $\left.K_{s}\right)$ were indicative of efficient COD and nitrogen removal from municipal wastewater. The kinetic coefficients obtained in this study are supportive of those calculated by Kundu et al. [1]. This proves that R31 has similar capacity to perform in terms of COD and nitrogen removal from slaughterhouse wastewater if used in a large-scale SND treatment plant. Kinetic coefficients for simultaneous carbon oxidation, nitrification, and denitrification by any Chryseobacterium species are being determined for the first time. Analysis of the kinetic coefficients is the best method for prediction of potential large-scale application of pure cultures and this approach has been described for the first time for bacteria capable of SND.

The Chryseobacterium genus was first described by Vandamme et al. [51] with six species and, following the revised description of the family Flavobacteriaceae by Bernardet et al. [52], more than sixty novel species of the genus Chryseobacterium have been identified from a large number of sources such as wastewater [53], contaminated soils [54], plant rhizosphere [55], human clinical source [56], chicken [57], fish [58], mosquito [59], glacier [60], and beer manufacturing [61]. However, most of the novel species have been reported from bovine milk $[36,62,63]$. Our isolate was obtained from slaughterhouse wastewater for the first time, and, to the best of our knowledge, nitrification and denitrification property within this genus is also being recorded for the first time. The Nitrosomonas genus having ammonia-oxidizing bacteria and the Nitrobacter genus comprising nitrite oxidizing bacteria are regarded as the principal genera of chemolithotrophic nitrifying bacteria. Accordingly, the probes required for fluorescence in situ hybridization (FISH), NSO1225, and NIT3 were selected to stain $\beta$-proteobacteria sp. AOB and Nitrobacter sp. NOB, respectively by Pan et al. [6] during their study on nitrogen removal from abattoir wastewater through partial nitrification and subsequent denitrification in intermittently aerated sequencing batch reactors. Authors justified the selection stating that both $\beta$-proteobacteria sp. AOB and Nitrobacter sp. NOB were widely found in wastewater systems. However, Yilmaz et al. [8] noted that common NOBs (Nitrobacter and Nitrospira) were not found in the sequential batch reactor during simultaneous nitrification, denitrification, and phosphate removal of abattoir wastewater. In consonance with the finding of Yilmaz et al. [8] and similar to our previous study [17], Nitrosomonas, Nitrobacter, and Nitrospira were not recovered as the most active nitrifiers/denitrifiers in the current investigation. Our two studies assert that novel microorganisms should be considered for simultaneous COD reduction, nitrification, and denitrification in slaughterhouse wastewater.

\section{Conclusions}

Through the present investigation a bacterium isolated from slaughterhouse wastewater was identified as Chryseobacterium sp. which successfully stabilized COD as well as ammonium nitrogen. The bacterium was capable of utilizing $\mathrm{NO}_{3}{ }^{-}-\mathrm{N}$ aerobically in presence of $\mathrm{NH}_{4}{ }^{+}-\mathrm{N}$. Nitrogen removal was dependent on the nature of the carbon substrate but independent of the type of the nitrogen substrate. This bacterium is a new member in the group of microbes capable of simultaneous removal of organic carbon and nitrogen from wastewater. Further taxonomic investigations are warranted to establish the strain as a new species. The kinetic coefficients of substrate removal and growth for concomitant carbon oxidation, nitrification, and denitrification are favorable and corroborative with the results of earlier researchers. The kinetic coefficients may be considered for the design of bioreactors, thus opening up the possibility of SND process in treatment of slaughterhouse wastewater.

\section{Conflict of Interests}

The authors declare that there is no conflict of interests regarding the publication of this paper.

\section{Authors' Contribution}

Contributions of Pradyut Kundu, Arnab Pramanik, and Arpita Dasgupta are equal in all respects.

\section{Acknowledgments}

Financial support from DST-PURSE and TEQIP programs of Jadavpur University is thankfully acknowledged.

\section{References}

[1] P. Kundu, A. Debsarkar, and S. Mukherjee, "Treatment of slaughter house wastewater in a sequencing batch reactor: performance evaluation and biodegradation kinetics," BioMed Research International, vol. 2013, Article ID 134872, 11 pages, 2013.

[2] C. F. Bustillo-Lecompte, M. Mehrvar, and E. Quiñones-Bolaños, "Combined anaerobic-aerobic and $\mathrm{UV} / \mathrm{H}_{2} \mathrm{O}_{2}$ processes for the treatment of synthetic slaughterhouse wastewater," Journal of Environmental Science and Health Part A, vol. 48, no. 9, pp. 11221135, 2013.

[3] J. B. R. Mees, S. D. Gomes, S. D. M. Hasan, B. M. Gomes, and M. A. V. Boas, "Nitrogen removal in a SBR operated with and without pre-denitrification: effect of the carbon: nitrogen ratio and the cycle time," Environmental Technology, vol. 35, no. 1, pp. 115-123, 2014.

[4] Y. Filali-Meknassi, M. Auriol, R. D. Tyagi, Y. Comeau, and R. Y. Surampalli, "Design strategy for a simultaneous nitrification/denitrification of a slaughterhouse wastewater in a sequencing batch reactor: ASM2d modeling and verification," Environmental Technology, vol. 26, no. 10, pp. 1081-1100, 2005.

[5] R. L. Meyer, R. J. Zeng, V. Giugliano, and L. L. Blackall, "Challenges for simultaneous nitrification, denitrification, and phosphorus removal in microbial aggregates: mass transfer 
limitation and nitrous oxide production," FEMS Microbiology Ecology, vol. 52, no. 3, pp. 329-338, 2005.

[6] M. Pan, L. G. Henry, R. Liu, X. Huang, and X. Zhan, "Nitrogen removal from slaughterhouse wastewater through partial nitrification followed by denitrification in intermittently aerated sequencing batch reactors at $11^{\circ} \mathrm{C}$," Environmental Technology, vol. 35, pp. 470-477, 2014.

[7] H.-Y. Zheng, Y. Liu, X.-Y. Gao, G.-M. Ai, L.-L. Miao, and Z.-P. Liu, "Characterization of a marine origin aerobic nitrifying-denitrifying bacterium," Journal of Bioscience and Bioengineering, vol. 114, no. 1, pp. 33-37, 2012.

[8] G. Yilmaz, R. Lemaire, J. Keller, and Z. Yuan, "Simultaneous nitrification, denitrification, and phosphorus removal from nutrient-rich industrial wastewater using granular sludge," Biotechnology and Bioengineering, vol. 100, no. 3, pp. 529-541, 2008.

[9] Q. Chen and J. Ni, "Ammonium removal by Agrobacterium sp. LAD9 capable of heterotrophic nitrification-aerobic denitrification," Journal of Bioscience and Bioengineering, vol. 113, no. 5, pp. 619-623, 2012.

[10] P. Chen, J. Li, Q. X. Li et al., "Simultaneous heterotrophic nitrification and aerobic denitrification by bacterium Rhodococcus sp. CPZ24," Bioresource Technology, vol. 116, pp. 266-270, 2012.

[11] H.-S. Joo, M. Hirai, and M. Shoda, "Characteristics of ammonium removal by heterotrophic nitrification-aerobic denitrification by Alcaligenes faecalis no. 4," Journal of Bioscience and Bioengineering, vol. 100, no. 2, pp. 184-191, 2005.

[12] A. A. Khardenavis, A. Kapley, and H. J. Purohit, "Simultaneous nitrification and denitrification by diverse Diaphorobacter sp," Applied Microbiology and Biotechnology, vol. 77, no. 2, pp. 403409, 2007.

[13] X.-P. Yang, S.-M. Wang, D.-W. Zhang, and L.-X. Zhou, "Isolation and nitrogen removal characteristics of an aerobic heterotrophic nitrifying-denitrifying bacterium, Bacillus subtilis A1," Bioresource Technology, vol. 102, no. 2, pp. 854-862, 2011.

[14] Q.-L. Zhang, Y. Liu, G.-M. Ai, L.-L. Miao, H.-Y. Zheng, and Z.-P. Liu, "The characteristics of a novel heterotrophic nitrificationaerobic denitrification bacterium, Bacillus methylotrophicus strain L7," Bioresource Technology, vol. 108, pp. 35-44, 2012.

[15] B. Zhao, Y. L. He, J. Hughes, and X. F. Zhang, "Heterotrophic nitrogen removal by a newly isolated Acinetobacter calcoaceticus HNR," Bioresource Technology, vol. 101, no. 14, pp. 5194-5200, 2010.

[16] S. K. Padhi, S. Tripathy, R. Sen, A. S. Mahapatra, S. Mohanty, and N. K. Maiti, "Characterisation of heterotrophic nitrifying and aerobic denitrifying Klebsiella pneumoniae CF-S9 strain for bioremediation of wastewater," International Biodeterioration and Biodegradation, vol. 78, pp. 67-73, 2013.

[17] P. Kundu, A. Pramanik, S. Mitra, J. D. Choudhury, J. Mukherjee, and S. Mukherjee, "Heterotrophic nitrification by Achromobacter xylosoxidans S18 isolated from a small-scale slaughterhouse wastewater," Bioprocess and Biosystems Engineering, vol. 35, no. 5, pp. 721-728, 2012.

[18] Metcalf and Eddy Inc., Wastewater Engineering Treatment Disposal Reuse, Tata McGraw-Hill, 3rd edition, 1995.

[19] J. Sambrook, E. F. Fritsch, and T. Maniatis, Molecular Cloning: A Laboratory Manual, Cold Spring Harbor Laboratory Press, Cold Spring Harbor, NY, USA, 2nd edition, 1989.

[20] A. V. Piterina, J. Bartlett, and J. Tony Pembroke, "Molecular analysis of bacterial community DNA in sludge undergoing autothermal thermophilic aerobic digestion (ATAD): pitfalls and improved methodology to enhance diversity recovery," Diversity, vol. 2, no. 4, pp. 505-526, 2010.
[21] J. F. Bernardet, C. J. Hugo, and B. Bruun, "Genus X. Chryseobacterium Vandamme, Bernardet, Segers, Kersters and Holmes," in Bergey's Manual of Systematic Bacteriology, W. B. Whitman, N. R. Krieg, J. T. Staley et al., Eds., vol. 4, pp. 180-192, 2nd edition, 2010.

[22] G. Barrow and R. K. A. Feltham, Cowan and Steel's Manual for the Identification of Medical Bacteria, Cambridge University Press, Cambridge, Mass, USA, 3rd edition, 1993.

[23] K.-H. Hinz, M. Ryll, and B. Köhler, "Detection of acid production from carbohydrates by Riemerella anatipestifer and related organisms using the buffered single substrate test," Veterinary Microbiology, vol. 60, no. 2-4, pp. 277-284, 1998.

[24] D. Gutnick, J. M. Calvo, T. Klopotowski, and B. N. Ames, "Compounds which serve as the sole source of carbon or nitrogen for Salmonella typhimurium LT-2," Journal of Bacteriology, vol. 100, no. 1, pp. 215-219, 1969.

[25] V. Møller, "Simplified tests for some amino acid decarboxylases and for the arginine dihydrolase system," Acta Pathologica et Microbiologica Scandinavica, vol. 36, no. 2, pp. 158-172, 1955.

[26] E. Fautz and H. Reichenbach, "A simple test for flexirubin-type pigments," FEMS Microbiology Letters, vol. 8, no. 2, pp. 87-91, 1980.

[27] P. R. Murray, E. J. Baron, M. A. Pfaller, F. C. Tenover, and R. H. Yolken, Manual of Clinical Microbiology, American Society for Microbiology, Washington, DC, USA, 6th edition, 1995.

[28] D. S. Frear and R. C. Burrell, "Spectrophotometric method for determining hydroxylamine reductase activity in higher plants," Analytical Chemistry, vol. 27, no. 10, pp. 1664-1665, 1955.

[29] M. Shoda and Y. Ishikawa, "Heterotrophic nitrification and aerobic denitrification of high-strength ammonium in anaerobically digested sludge by Alcaligenes faecalis strain No. 4," Journal of Bioscience and Bioengineering, vol. 117, no. 6, pp. 737741, 2014.

[30] J.-J. Su, B.-Y. Liu, and C.-Y. Liu, "Comparison of aerobic denitrification under high oxygen atmosphere by Thiosphaera pantotropha ATCC 35512 and Pseudomonas stutzeri SU2 newly isolated from the activated sludge of a piggery wastewater treatment system," Journal of Applied Microbiology, vol. 90, no. 3, pp. 457-462, 2001.

[31] B. Zhao, Q. An, Y. L. He, and J. S. Guo, " $\mathrm{N}_{2} \mathrm{O}$ and $\mathrm{N}_{2}$ production during heterotrophic nitrification by Alcaligenes faecalis strain NR," Bioresource Technology, vol. 116, pp. 379-385, 2012.

[32] L. A. Robertson and J. G. Kuenen, "Heterotrophic nitrification in Thiosphaera pantotropha: oxygen uptake and enzyme studies," Journal of General Microbiology, vol. 134, pp. 857-863, 1988.

[33] M. Kim, S.-Y. Jeong, S. J. Yoon et al., "Aerobic denitrification of Pseudomonas putida AD-21 at Different C/N ratios," Journal of Bioscience and Bioengineering, vol. 106, no. 5, pp. 498-502, 2008.

[34] A. W. Lawrence and P. L. McCarty, "Unified basis for biological treatment design and operation," Journal of the Sanitary Engineering Division-ASCE, vol. 96, pp. 757-778, 1970.

[35] O.-S. Kim, Y.-J. Cho, K. Lee et al., "Introducing EzTaxon-e: a prokaryotic 16s rRNA gene sequence database with phylotypes that represent uncultured species," International Journal of Systematic and Evolutionary Microbiology, vol. 62, no. 3, pp. 716721, 2012.

[36] E. Hantsis-Zacharov and M. Halpern, "Chryseobacterium haifense sp. nov., a psychrotolerant bacterium isolated from raw milk," International Journal of Systematic and Evolutionary Microbiology, vol. 57, no. 10, pp. 2344-2348, 2007.

[37] L. A. Fernández, E. B. Perotti, M. A. Sagardoy, and M. A. Gómez, "Denitrification activity of Bradyrhizobium sp. isolated from Argentine soybean cultivated soils," World Journal of 
Microbiology and Biotechnology, vol. 24, no. 11, pp. 2577-2585, 2008.

[38] N. G. Quintans, V. Blancato, G. Repizo, C. Magni, and P. Lopez, "Citrate metabolism and aroma compound production in lactic acid bacteria," in Molecular Aspects of Lactic Acid Bacteria for Traditional and New Applications, Research Signpost, B. Mayo, P. Lopez, and G. P. Martinez, Eds., pp. 65-88, Kerala, India, 2008.

[39] B. Wei, S. Shin, D. Laporte, A. J. Wolfe, and T. Romeo, "Global regulatory mutations in $c s r A$ and $r p o S$ cause severe central carbon stress in Escherichia coli in the presence of acetate," Journal of Bacteriology, vol. 182, no. 6, pp. 1632-1640, 2000.

[40] H. Eoh and K. Y. Rhee, "Multifunctional essentiality of succinate metabolism in adaptation to hypoxia in Mycobacterium tuberculosis," Proceedings of the National Academy of Sciences of the United States of America, vol. 110, no. 16, pp. 6554-6559, 2013.

[41] D. J. Richardson, J.-M. Wehrfritz, A. Keech et al., "The diversity of redox proteins involved in bacterial heterotrophic nitrification and aerobic denitrification," Biochemical Society Transactions, vol. 26, no. 3, pp. 401-408, 1998.

[42] L. D. Kuykendall, "Order VI. Rhizobiales ord. nov.," in Bergey's Manual of Systematic Bacteriology, (the Proteobacteria), Part C (the Alpha-, Beta-, Delta-, and Epsilonproteobacteria), D. J. Brenner, N. R. Krieg, J. T. Staley, and G. M. Garrity, Eds., vol. 2, pp. 324-340, 2nd edition, 2005.

[43] K. S. Bell, J. C. Philp, D. W. J. Aw, and N. Christofi, "A review: the genus Rhodococcus," Journal of Applied Microbiology, vol. 85, no. 2, pp. 195-210, 1998.

[44] H. J. Busse and G. Auling, "Genus I. Alcaligenes," in Bergey's Manual of Systematic Bacteriology, (the Proteobacteria), Part C (the Alpha-, Beta-, Delta-, and Epsilonproteobacteria), D. J. Brenner, N. R. Krieg, J. T. Staley, and G. M. Garrity, Eds., vol. 2, pp. 653-658, 2nd edition, 2005.

[45] K. Towner, "The genus Acinetobacter," in The Prokaryotes: A Handbook on the Biology of Bacteria: Proteobacteria: Gamma Subclass, M. Dworkin, S. Falkow, E. Rosenberg, K. H. Schleifer, and E. Stackebrandt, Eds., vol. 6, pp. 746-758, 3rd edition, 2006.

[46] J. P. Bowman and T. A. Mcmeekin, "Genus VII. Marinobacter," in Bergey's Manual of Systematic Bacteriology, (the Proteobacteria), Part B (the Gammaproteobacteria), D. J. Brenner, N. R. Krieg, J. T. Staley, and G. M. Garrity, Eds., vol. 2, pp. 459-464, 2nd edition, 2005.

[47] R. A. Slepecky and H. E. Hemphill, "The genus BacillusNonmedical," in The Prokaryotes: A Handbook on the Biology of Bacteria: Bacteria: Firmicutes, Cyanobacteria, M. Dworkin, S. Falkow, E. Rosenberg, K. H. Schleifer, and E. Stackebrandt, Eds., vol. 4, pp. 530-562, 3rd edition, 2006.

[48] P. A. D. Grimont and F. Grimont, "Genus XVI. Klebsiella," in Bergey's Manual of Systematic Bacteriology, (the Proteobacteria), Part B (the Gammaproteobacteria), D. J. Brenner, N. R. Krieg, J. T. Staley, and G. M. Garrity, Eds., vol. 2, pp. 685-693, 2nd edition, 2005.

[49] K. Cho, D. X. Nguyen, S. Lee, and S. Hwang, "Use of realtime QPCR in biokinetics and modeling of two different ammonia-oxidizing bacteria growing simultaneously," Journal of Industrial Microbiology and Biotechnology, vol. 40, pp. 10151022, 2013.

[50] A. Pala and Ö. Bölükbaş, "Evaluation of kinetic parameters for biological CNP removal from a municipal wastewater through batch tests," Process Biochemistry, vol. 40, no. 2, pp. 629-635, 2005.

[51] P. Vandamme, J.-F. Bernardet, P. Segers, K. Kersters, and B. Holmes, "New perspectives in the classification of the flavobacteria: description of Chryseobacterium gen. nov., Bergeyella gen. nov., and Empedobacter nom. rev," International Journal of Systematic Bacteriology, vol. 44, no. 4, pp. 827-831, 1994.

[52] J.-F. Bernardet, Y. Nakagawa, B. Holmes et al., "Proposed minimal standards for describing new taxa of the family Flavobacteriaceae and emended description of the family," International Journal of Systematic and Evolutionary Microbiology, vol. 52, no. 3, pp. 1049-1070, 2002.

[53] J.-H. Yoon, S.-J. Kang, and T.-K. Oh, "Chryseobacterium daeguense sp. nov., isolated from wastewater of a textile dye works," International Journal of Systematic and Evolutionary Microbiology, vol. 57, no. 6, pp. 1355-1359, 2007.

[54] S. Szoboszlay, B. Atzél, J. Kukolya et al., "Chryseobacterium hungaricum sp. nov., isolated from hydrocarbon-contaminated soil," International Journal of Systematic and Evolutionary Microbiology, vol. 58, no. 12, pp. 2748-2754, 2008.

[55] C.-C. Young, P. Kämpfer, F.-T. Shen, W.-A. Lai, and A. B. Arun, "Chryseobacterium formosense sp. nov., isolated from the rhizosphere of Lactuca sativa L. (garden lettuce)," International Journal of Systematic and Evolutionary Microbiology, vol. 55, no. 1, pp. 423-426, 2005.

[56] A. F. Yassin, H. Hupfer, C. Siering, and H.-J. Busse, "Chryseobacterium treverense sp. nov., isolated from a human clinical source," International Journal of Systematic and Evolutionary Microbiology, vol. 60, no. 9, pp. 1993-1998, 2010.

[57] H. de Beer, C. J. Hugo, P. J. Jooste et al., "Chryseobacterium vrystaatense sp. nov., isolated from raw chicken in a chickenprocessing plant," International Journal of Systematic and Evolutionary Microbiology, vol. 55, no. 5, pp. 2149-2153, 2005.

[58] H. De Beer, C. J. Hugo, P. J. Jooste, M. Vancanneyt, T. Coenye, and P. Vandamme, "Chryseobacterium piscium sp. nov., isolated from fish of the South Atlantic Ocean off South Africa," International Journal of Systematic and Evolutionary Microbiology, vol. 56, no. 6, pp. 1317-1322, 2006.

[59] P. Kämpfer, K. Chandel, G. B. K. S. Prasad, Y. S. Shouche, and V. Veer, "Chryseobacterium culicis sp. nov., isolated from the midgut of the mosquito Culex quinquefasciatus," International Journal of Systematic and Evolutionary Microbiology, vol. 60, no. 10, pp. 2387-2391, 2010.

[60] F. Bajerski, L. Ganzert, K. Mangelsdorf, L. Padur, A. Lipski, and D. Wagner, "Chryseobacterium frigidisoli sp. nov., a psychrotolerant species of the family Flavobacteriaceae isolated from sandy permafrost from a glacier forefield," International Journal of Systematic and Evolutionary Microbiology, vol. 63, no. 7, pp. 2666-2671, 2013.

[61] P. Herzog, I. Winkler, D. Wolking, P. Kämpfer, and A. Lipski, "Chryseobacterium ureilyticum sp. nov., Chryseobacterium gambrini sp. nov., Chryseobacterium pallidum sp. nov. and Chryseobacterium molle sp. nov., isolated from beer-bottling plants," International Journal of Systematic and Evolutionary Microbiology, vol. 58, no. 1, pp. 26-33, 2008.

[62] E. Hantsis-Zacharov, T. Shakéd, Y. Senderovich, and M. Halpern, "Chryseobacterium oranimense sp. nov., a psychrotolerant, proteolytic and lipolytic bacterium isolated from raw cow's milk," International Journal of Systematic and Evolutionary Microbiology, vol. 58, no. 11, pp. 2635-2639, 2008.

[63] E. Hantsis-Zacharov, Y. Senderovich, and M. Halpern, "Chryseobacterium bovis sp. nov., isolated from raw cow's milk," International Journal of Systematic and Evolutionary Microbiology, vol. 58, no. 4, pp. 1024-1028, 2008. 

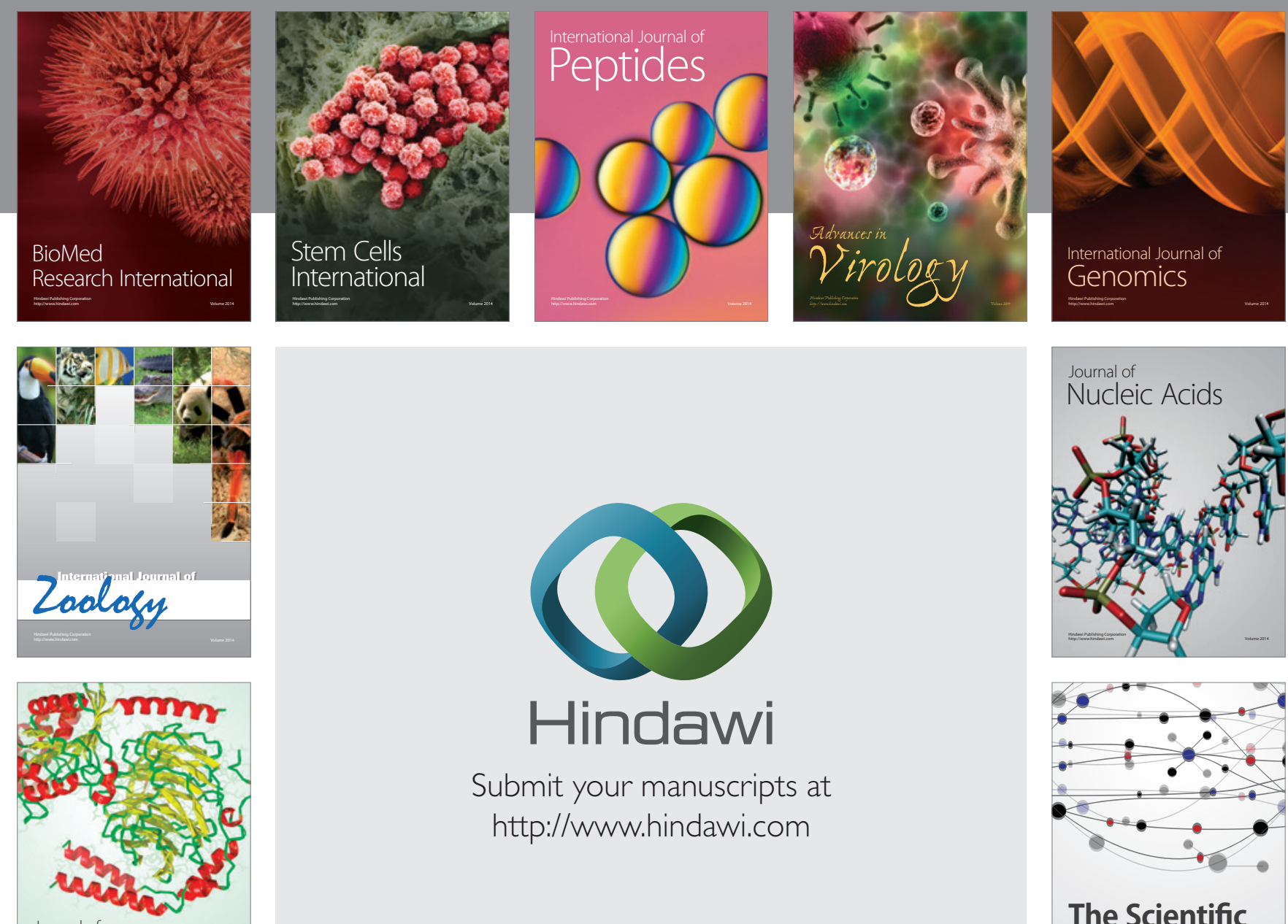

Submit your manuscripts at

http://www.hindawi.com

Journal of
Signal Transduction
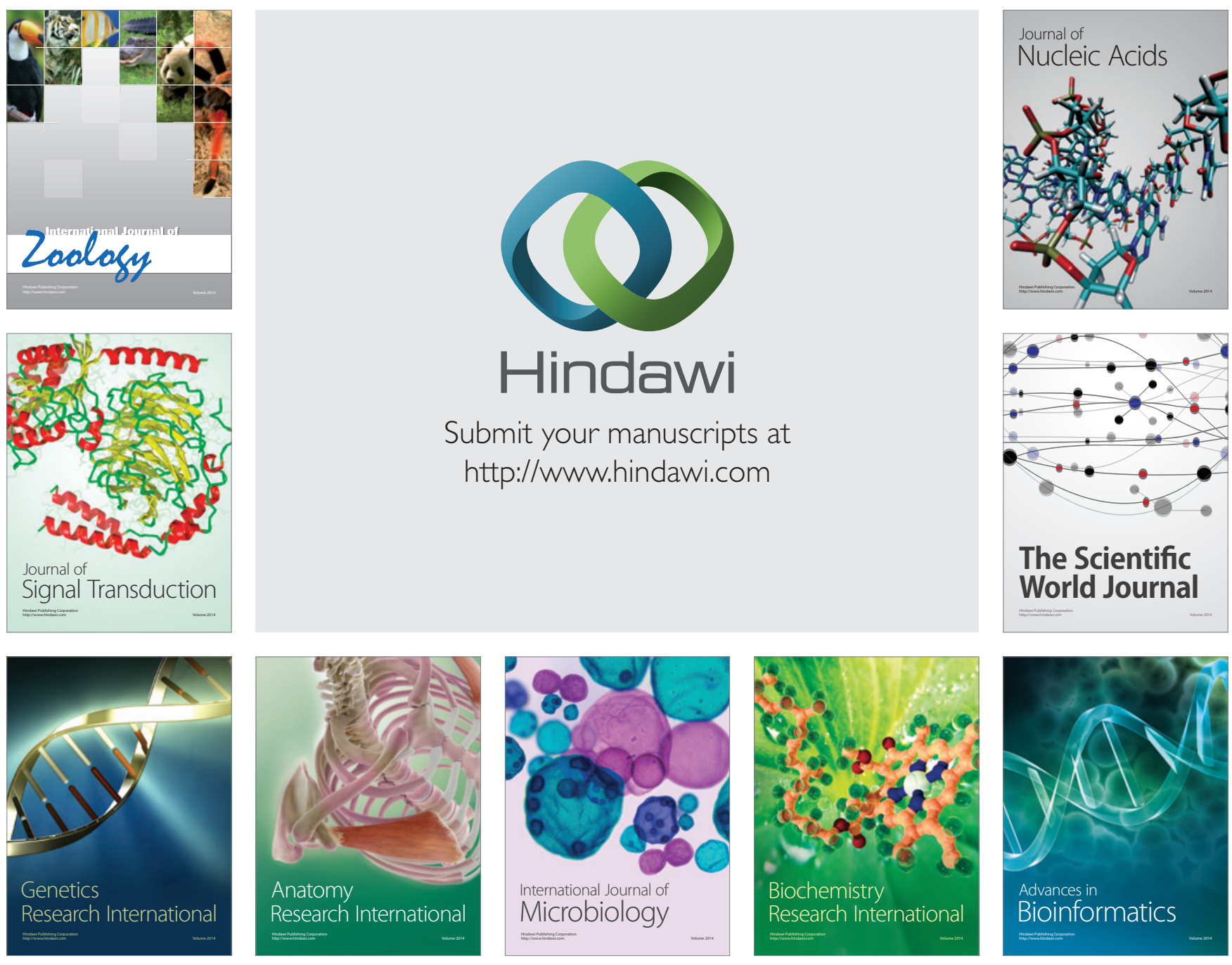

The Scientific World Journal
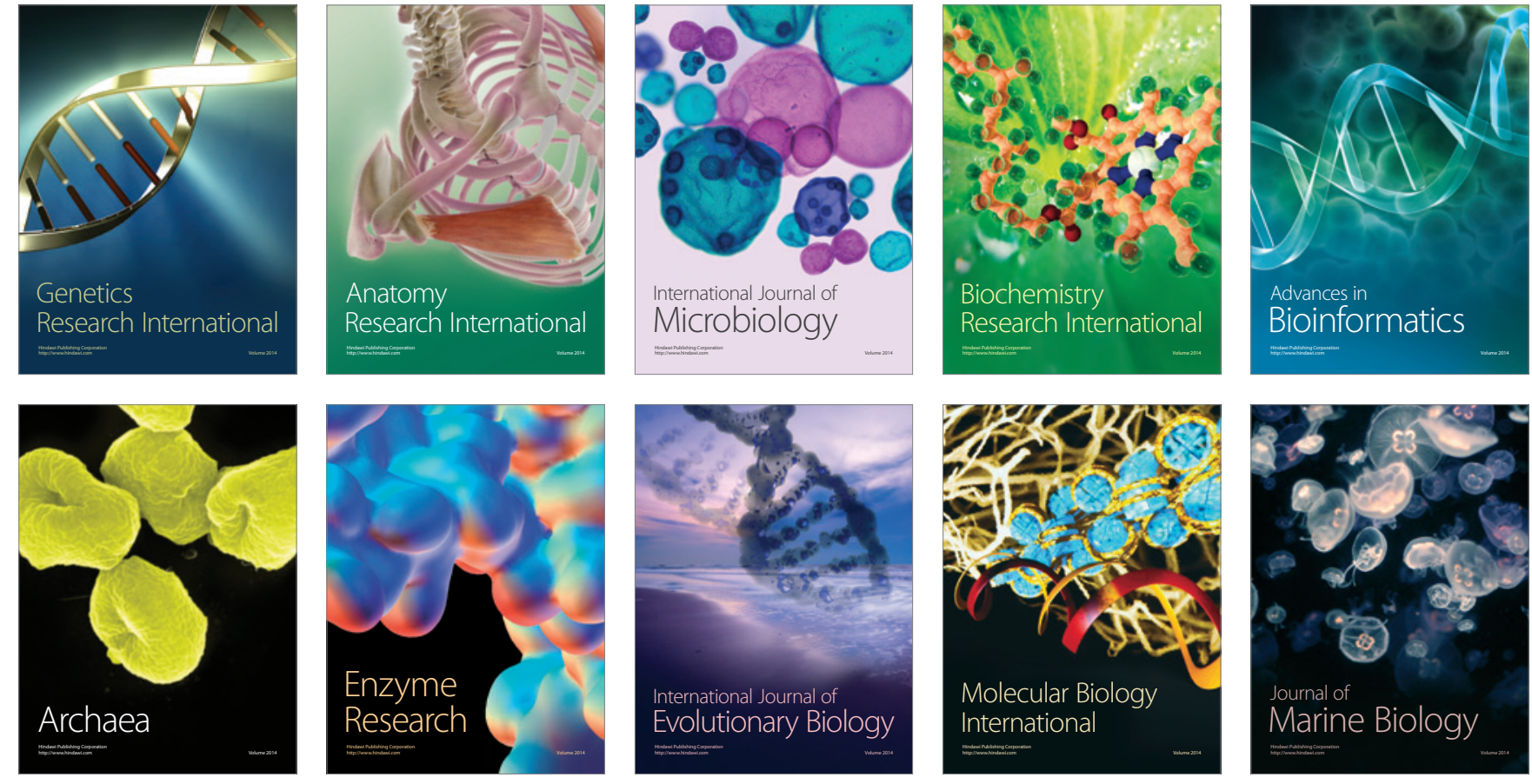